\title{
THE EXTENT OF MEDIA INFLUENCE ON THE BODY IMAGE OF MALAYSIAN EMERGING ADULTS
}

(D) Naginder Kaur ${ }^{1+}$
iD Siti Sarina
Sulaiman
iD Huzaifah A.
Hamid $^{3}$
(D) Norlizawati
Ghazali $^{4}$
(D) Amizura Hanadi
Mohd Radzi
(D) Yang Salehah
Abdullah Sani

\section{Article History}

Received: 10 November 2021 Revised: 23 December 2021 Accepted: 6 January 2022 Published: 20 January 2022

\section{Keywords}

Emerging adults Malaysian young adults

Mass media

Social media

Body image Advertising.

\author{
${ }_{1,9,9,4,5,6}$ Academy of Language Studies, University Technology MARA, Perlis, \\ Malaysia. \\ 'Email:ninder@uitm.edu.my \\ ${ }^{2}$ Emailisitisarina@uitm.edu.my \\ ${ }^{s}$ Email:huzaifahhamid@uitm.edu.my \\ "Email:norlizawati@uitm.edu.my \\ ${ }^{5}$ Email:amizura@uitm.edu.my \\ ${ }^{6}$ Email:yangsalehah@uitm.edu.my
}

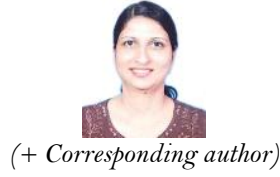

ABSTRACT

Body image includes two aspects which are one's perceptions towards one's body size, weight, shape, as well as physical attributes or movements and feelings about these attributes, which consequently impact one's behaviour. In this regard, the media plays a key role in defining emerging adults' self-beliefs about themselves and how these attributes are further translated into behavioural outcomes. Guided by the Sociocultural Theory, this study is undertaken to probe the extent of media influence on Malaysian emerging adults' body image and how this influence exerts on their emotions and behaviours. Through purposive sampling technique on 227 emerging adults enrolled at a Malaysian public university, a questionnaire probed the causal role of the media and its effects on the body image of these young adults. The study found that the media, particularly social media has a strong and significant influence on Malaysian emerging adults. However, a noteworthy finding is that the emotional states experienced by young adults are not always negative. Despite the constant flooding of advertisements on ideal beauty, weight and skin tone, the majority take the more rational and positive route in improving themselves and their body image by opting for exercise and change in diet regime. This implies that educators, parents, policy makers and the society at large need to constantly awaken the minds of the youth about the inevitable impact of the media and care should be taken to ensure frequent reinforcements and mitigation approaches.

Contribution/Originality: This study documents noteworthy findings that the media, particularly social media exerts its influence on the body image of both females and males. However, Malaysian emerging adults demonstrate commendable degree of maturity and are rational in confronting the flurry of media advertisements that constantly come their way.

\section{INTRODUCTION}

Body image is a multifaceted construct that encompasses one's perceptions and attitudes towards one's body size and shape (Mills, Shannon, \& Hogue, 2017). It essentially constitutes two major aspects which include a) perceptions of the body size, weight, shape, and physical attributes of performance and movements, and b) feelings about these attributes, which consequently affect one’s behaviour. 
In forming one's body image, various factors can impinge one's perceptions and concerns of beauty as well as one's emotions, one of which is the media, namely, the printed media (newspaper, magazine, brochure, flyers), electronic media (television, radio, music video) and social media (namely Facebook, Instagram, TikTok). There is robust empirical support to reaffirm that exposure to media alters and transforms self-perceptions and body image of both males and females (Mills et al., 2017).

Emerging adults, that is adults who are in between adolescence and early adulthood, are generally between 18 and 29 years of age, as defined by Jeffrey Jensen Arnett in 1995. This in-between stage of life is filled with episodes of transience, change, non-stability and impermanence, such as transitions at educational institutions, change in roommates, house mates, and work colleagues. Additionally, the cusp of adulthood or the early stage of adulthood is also a phase of self-focus and possibilities (Munsey, 2006) as one begins to seek more lasting relationships and marriage prospects. The extent to which an individual is able to find liberty, both in mind and action largely depends on the type of support received from their environment and society (Munsey, 2006). In this regard, the media plays a key role in defining emerging adults' self-beliefs about themselves, including beliefs about their physical attributes and how these attributes are further translated into behavioural outcomes.

This study is therefore undertaken to probe the extent of media influence on young emerging adults' body image and how this influence is exerted on their emotions and behavioural consequences of the young adults in Malaysia. The scope of enquiry is to find out young people's perceptions of the role played by the media in portraying ideal body image and how this determines the body image of Malaysian young men and young women. The study also attempts to find out how media advertisements affect young people's emotions about their body image and provides further insights into their behavioural responses towards media advertising in Malaysia. The research questions formulated in this study are:

1. What are Malaysian emerging adults' perceptions of the role of media in determining the body image of young men and young women?

2. How do media advertisements affect Malaysian emerging adults' emotions about their body image?

3. What are Malaysian emerging adults' behavioural responses towards media advertising?

The study is guided by the sociocultural theory of body image postulated by Thompson, Heinberg, Altabe, and Tantleff-Dunn (1999) which posits that mass media has a direct influence on societal expectations of ideal weight and beauty, through several domains, such as news media, advertising, and social media. This study specifically focuses on the role of social media, and the different ways body image is portrayed by social media platforms and how this is ingrained in the minds of Malaysian emerging adults.

The term emerging adults in this study relates to individuals between the ages of 20 and 29 , however, the majority of emerging adults in this study are below 25 years old. As such, the study is limited in its scope as the emerging adults surveyed in this study are students enrolled at an institution of higher learning in Malaysia and exclude emerging adults who have or are beginning to embark on their career path.

\section{LITERATURE REVIEW}

\subsection{Socio-Cultural Theory}

Sociocultural Theory essentially emphasises the integral role of one's cultural milieu and of one's society on one's individual development (Vygotsky, 1978, as cited in Tehranian (2013)). Socio-cultural variables refer to ways "in which the core themes of society, namely the 'body-ideal' and importance of appearance are transmitted to and influence individuals" (George, 2010). The notion of being thin as ideal is transmitted and reinforced through repetitive encounters with various mechanisms, namely, parents, peers, as well as the media. These three mechanics and sources of influence have been highlighted as 'transmitters' of socio-cultural themes (Stice \& Agras, 1998, as cited in George (2010)). Of all the transmitters of socio-cultural themes, the mass media is arguably regarded as one of the most powerful promoters of the ideal body in Western cultures (George, 2010; Tiggemann, 2003). In today's world 
of the $21^{\text {st }}$ century, the media is a powerful defining force within a society, as the young generation identify with and are defined by technology and innovation (Tiggemann, 2003). Various studies suggest that $21^{\text {st }}$ century media dramatically influence social and emotional development of young people (see (George, 2010; Tiggemann, 2003)).

In defining one's body image, implicitly and explicitly, the media is instrumental in insinuating women to internalise the notion that a very slender female body type is ideal or beautiful. The media, a socio-cultural variable and intermediary mechanism consequently results in body image disturbances and eating disorders. Therefore, sociocultural theory primarily portrays women's body as a mere object and insinuates thinness as perfection while a fat physical appearance is viewed as unfavourable and unattractive.

\subsection{The Media Industry and Its Influence on Body Image}

For decades the media has paved its way in the thought and life of many young minds, women and men alike, telling them that they somehow need to be fixed or upgraded in order to achieve the ever-changing definition of body perfection. Its influence even goes as far as telling society that attractive people are more desirable, reliable, and inspirational (Solomon, Ashmore, \& Longo, 1992). Advertisers especially are always looking for new and creative ways to rope in young viewers by going as far as putting up flyers and magazines at schools, even in the bathroom, stalls, and via the Internet (Barve, Sood, Nithya, \& Virmani, 2015). The media is constantly showing something new in body looks, fashion, and diet fad, telling viewers repetitively that who (the person) they are currently might not be ideal enough to be a part of the society. Young people, especially children are susceptible to influences from media including traditional media sources (Olsen, 2015) such as television, cinema, radio, the Internet, and printed media, consequently affecting their understanding of their own bodies and the damaging standard they believe they need to achieve in order to be attractive (Moy, 2015). The most common victim to this is often adolescent girls who are more susceptible to the idea of an ideal body image, causing them to experience "body image dissatisfaction" (Knauss, Paxton, \& Alsaker, 2007). A study by Aruna and Shradha (2008, as cited in Dromgoole (2011)) explored the issue of media effects and body image perceptions on youth. The result indicated that television advertisements affect both male and female viewers equally. Female youths desire to be as thin as the spokesperson they see on television, who are often $23 \%$ thinner than the average woman, whereas the males felt the pressure to be as muscular as the models they saw on product advertisements. When there is a large discrepancy between perceived self-image and the body ideal, there is a high probability that it will generate a high level of anxiety within the individual which will more often than not, lead to the creation of a truly negative self-concept and a worrying depressive state (Reategui \& Palmer, 2017).

The media industry's influence in determining the current trend of beauty and ideal body image is centralised not only in the western part of the world but is also well-rooted all around the world. While the concept of ideal body image fed by the media varies between countries and cultures, its effect is nevertheless similar. For example, in Malaysia, CLEO, an Australian based beauty magazine, has become an important influence in Malaysia since 1995. While this magazine focuses on its female readers, one of its main attractions is its yearly CLEO Most Eligible Award, where the candidates would share their lifestyle and promote male beauty and healthcare products to male readers. Yan and Bissell (2014), as well as Rickert and Sacharow (2000) reported survey results regarding viewers of teentargeted fashion magazine websites. Majority of the viewers were teenage girls between the ages of 12-17, making up $50.7 \%$ of those who visited CosmoGIRL!, $42.6 \%$ visited TeenPeople, and $38.6 \%$ visited Seventeen magazine site (Yan \& Bissell, 2014). A previous study by Tiggemann (2003) found there was a positive correlation between the internalization of the thin body image idea with reading magazines. Earlier, Harrison (2000) reported that for young female readers $\left(9^{\text {th }}\right.$ and $12^{\text {th }}$ graders), reading such magazines which exposed them to thin-ideal content was a step into possible bulimia.

Multiple studies have been conducted to address concerns over the society's increasing obsession towards achieving the ideal body image as portrayed by the media (Baird \& Grieve, 2006; Grabe, Hyde, \& Ward, 2008; Luo, 
Parish, \& Laumann, 2005; Tang \& Chen, 2013; Zhang, 2012, as cited in Bergenholtz (2014)). In Asian countries, with the rapid development of the fashion industry, health and fitness related industry advertised by the media, more people are influenced by the idea of how they should and are expected to look like (Bergenholtz, 2014). In his study, Bergenholtz also stated that while traditionally in China, having a chubby or full figure is considered a prosperous sign of wealth and health, the contradictory image portrayed in the media, which favours slimmer and thinner figures, causing confusion amongst those exposed to it. Many young individuals, especially women, from Korea, Japan and Taiwan believe themselves to be overweight or obese when the fact is far from it due the 'thin ideal' exposure via television, magazine, film, social media, and advertisements (Noh, Kwon, Yang, Cheon, \& Kim, 2018). In the Western society, media portrayal of unrealistic body image standard by role models such as influencers, actors, athletes and models (Koyuncu, Tok, Canpolat, \& Catikkas, 2010), music video, and movies have caused high body dissatisfaction among adolescents (Croll, 2005; Ferguson, Muñoz, Garza, \& Galindo, 2014), as they affect the adolescents' view of ideal body image to be thin and lean for females and strong and lean for males.

\subsection{Social Media, Body Image and Youth}

A theory by Gerbner and Gross (1976), the Cultivation theory, surmises that overexposure to mass media such as television could influence and lead the viewers' perspectives and lifestyle into a singular spectrum. This, unfortunately, often leads to negative impacts and now with the growth of the Internet and various media platforms, the damage radius is also expanding, and the impacts are more severe compared to other mediums. Based on a report, Internet User Survey 2020 (Malaysian Communications and Multimedia Commision, 2020), youth from generation $\mathrm{Z}$ (born between 1997 and 2012), are the main Internet users (43.8\%) compared to the millennials or generation Y, generation X, and baby boomers. When social media such as Facebook started to make its presence in Malaysia in early 2000, it gained instant popularity, especially among youth. Today, there are more and more people who turn to social media for the sole purpose of self-confirmation. According to Digital in 2021 Report (Kemp, 2021) as at January 2021 , there are more than 4.66 billion Internet users globally, of which 4.2 billion are social media users. Ranking at 22 from the 47 listed countries, Malaysia with 32.75 million population, shows that the number of its Internet users has increased by 738,000 or $2.8 \%$ as compared to 2020 , totaling 27.43 million users. This is whopping data as Internet users account for $84.2 \%$ of the country's population. In relation to this, the number of active social media users is reported to be 28 million, showing a staggering increase of two million users - 7.7\% between January 2020 to January 2021. In January 2021, Facebook was recorded as the most frequently used social media site globally (2.74 billion) while YouTube is recorded as the most visited social media website in Malaysia (93.7\%), followed by several other most frequently used social media platforms such as WhatsApp (91.9\%), Facebook (89.1\%), Instagram (74.7\%), Facebook Messenger (64.3\%), Twitter (49.0\%), WeChat (41.5\%), Telegram (37.8\%) and TikTok (35.5\%) (Kemp, 2021). These percentages illustrate the influence the social media has on its users and with the current global situation of the pandemic where working from home has become a mainstay in many parts of the world, it will not be surprising if these numbers climb even higher.

In the social media age, the emergence of body image influencers is also growing rapidly. A social media influencer is defined as someone who has the ability or authority to influence others in a certain niche due to their knowledge, position or even relationship with their audiences (Geyser, 2021). Body image trends on social media are constantly evolving. Some are promoted via online challenges using online platforms like TikTok and Weibo while some others may be downright dangerous. One day big lips are in, the next month it could be about having a prominent thigh gap and currently, it is all about the tiny waist and wide hips. In 2015, there was a thinness trend that went viral via Weibo, China's version of Twitter. The 'Collarbone Challenge' was where a person could measure their thinness by lining up coins in their collarbones and the more coins your collarbones could carry the more attractive, skinny and sexy you were considered to be (Brown, 2015). Then there was the Kylie Jenner Lip Challenge posted on her Instagram in 2015, where she shared her 'tips' on having big, luscious lips. There were multiple reports 
and videos showing disastrous results as this challenge did not produce the expected result and could possibly cause permanent damage (Moyer, 2015). Subsequently, a TikTok user found herself scarred with facial burns and temporary blindness when she attempted a beauty tip that went viral on the app for temporary faux-freckles (Schiffer, 2021). While it is unfair to overgeneralize social media as a toxic medium to prevent a healthy body image, studies have proven that social media too, plays an impactful role in distorting a person's expectation in appreciating their own body. Posting an image on social media for "likes" could boost a person's perception of body image but seeing others' selfies that might get more "likes" than your own, might cause disappointment and negative perception of body image (Ahmad, Idris, \& Jing, 2019; Chua \& Chang, 2016; Grogan, 2016; Tiidenberg, 2014). Holland and Tiggemann (2016) reported that those who engaged more in self-photo related activities on social media scored higher levels of bodyrelated and eating concerns. For example, women who often post fitness and inspirational images, or fitspiration for short, on social media, have been found to score higher on eating disorder scores.

It is rather apparent that the body-image trend on social media is not going away anytime soon or perhaps will never do. This needs to be constantly monitored and considered as its impact on body image and self-esteem could lead to bigger problems such as eating disorders and depression, as found by many researchers. However, most of these studies cover the issue in the Western context. While there are several similar studies carried out in Malaysia, the perspective focuses more on the correlation between body image and self-esteem without really relating it as a possible impact from social media usage. This study is hence, timely to investigate the Malaysian emerging adults' perceptions, and the causal relationship these have with their emotions and behavioural responses towards media advertising.

\section{METHODOLOGY}

Purposive sampling technique was used to obtain data for this study. The selected participants comprised a cohort of 227 emerging adults, enrolled at a public university in Malaysia. There were 84 males and 147 females in this study, pursuing various undergraduate programmes. They were 19-25 years old, while the majority (94.7\%) were 20 years old.

A questionnaire was devised to probe the causal role played by the media and the effects it exerts on the body image of these young adults. The survey instrument comprised five demographic questions and 15 closed and openended questions. Data collection phase of two weeks obtained input and insights via Google form questionnaire. Subsequently, the data was analysed in the SPSSv.25 tool by running t-tests, chi square tests and obtaining frequency scores. The open-ended answers were thematically analysed and salient themes were categorised accordingly. A focus group interview was also conducted with 10 participants on Google Meet platform to obtain further insights and input from the emergent adults at this site. Demographic information of the respondents was obtained to understand their responses about the media in a better way. The average weight for the males was between 55 to $74 \mathrm{~kg}$, while the females weighed between 40 to $59 \mathrm{~kg}$ on average, which means none of the respondents was really obese, but had body weight of a regular emerging adult. The average male height was recorded between 161-170cm and for young female adults, they were within 156 to $160 \mathrm{~cm}$ tall.

\section{FINDINGS AND DISCUSSION}

\subsection{Emerging Adult's Perceptions of the Role of Media in Determining Body Image}

From the findings obtained from 227 emerging adults, it is conspicuously evident that social media is the most significant type of media influence on young adults' perfect body image today (see Figure 1). This is anticipated and confirmatory of the statistics reported by Kemp (2021) of the staggering 28 million Malaysian social media users. Only nine participants attribute printed and electronic media as the most influential source, confirming that children are more influenced by the television and hardcopies of newspapers or magazines (Olsen, 2015) in comparison to young adults or youths. 


\section{Media Influence on Perceptions of a 'Perfect' Body Image?}

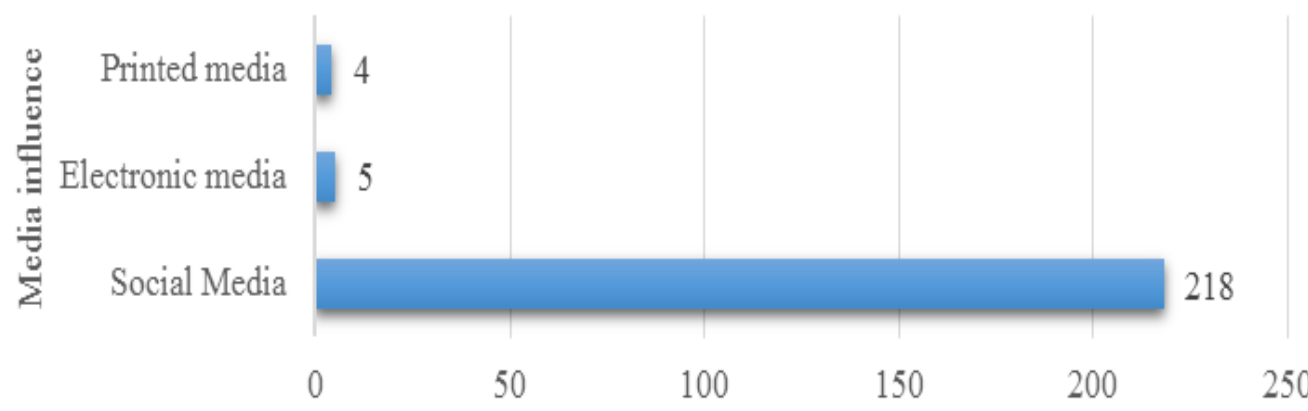

Figure 1. Influence of different types of media on perceptions of a "perfect" body image.

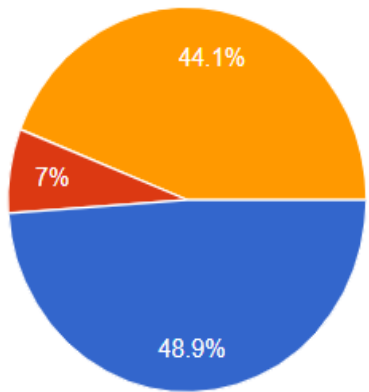

Female Percentage

Figure 2. Percentage of agreement on media influence among males and females

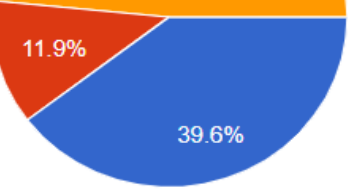

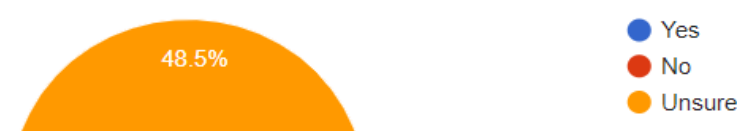

$39.6 \%$

Male Percentage 
more and more endorsed products advertised in the media, hence, to say that only females are vain and narcissistic in this present day and age would be a misrepresentation of the actual situation at hand.

The participants also found females to be more inaccurately portrayed (88.5\%) in comparison to the inaccurate media depiction of males $(11.5 \%)$. The participants said that as a solution for a more positive body image among young adults, the majority (74.4\%) postulated that media ought to reflect the average body type instead of feeding extreme hourglass thinness, or flawless complexion over the media. One respondent contended that:

“... if they use different type of body, it will make us realise that we live in a world that have different

body, different skin, different facial structure etc. It is okay to be different. We should not push ourselves too hard to make our body as beautiful as models."

While this would be the ideal expectation of the media, as expressed by the majority of the respondents, they nevertheless expressed concerns regarding the technological ability possessed by media which allows both advertisers and users to manipulate male and female image to create a figure of "perfection", as defined by the current trend. This figure is then promoted to the public using the media platform, causing not only false expectations of how a female or male body should look like but at the same time, the promoted image confuses many of them since they do not know whether they can really trust the authenticity of this image. One respondent pointed that: "media frequently portray and glorify people with fair skin complexion and skinny, a petite body which changes people perspectives on healthy body image they should have." Another respondent also argued how such images are so unrealistic because it places a certain amount of pressure of the portrayed beauty standard:

“...you have to be skinny and have fair skin but at the same time have this body figured which required fat at a certain area, your belly should be flat or else you will be considered as fat, your skin should look like A4 paper especially in Malaysia.'

Almost half the participants $(48.89 \%)$ concurred that the media bears the responsibility when of portraying certain body image since the accessibility rate to media nowadays is much higher and more and more younger audience are drawn to social media. Several respondents even collectively agreed that these 'doctored' images not only could raise their sense of insecurity about their body image but at the same time could also trigger anxiety disorders.

\subsection{Media Advertisements' Effect on Emotions about Body Image}

In probing the emotional effect of the way media portrays male and female adolescents and adults, chi-square test (see Table 2) revealed that there is statistically significant relationship between media advertisements and Malaysian emerging adults' emotions about their body image; $\chi 2(2)=30.591, \mathrm{p}<0.05$; that is, media advertisements do affect Malaysian emerging adults' emotions about their body image.

Table 2. Chi square test on relationship between media advertisements and emerging adults' emotions about body image.

\begin{tabular}{l|c|c|c}
\hline Chi-Square Tests \\
\hline & Value & df & Asymptotic Significance (2-sided) \\
\hline Pearson Chi-Square & $30.591^{\mathrm{a}}$ & 2 & 0.000 \\
\hline Likelihood Ratio & 30.202 & 2 & 0.000 \\
\hline Linear-by-Linear Association & 27.977 & 1 & 0.000 \\
\hline N of Valid Cases & 227 & & \\
\hline
\end{tabular}

However, further analysis of descriptive statistics and interview data reveal that the effect / correlation does not revolve around negative emotions as a quarter of these emerging adults (25\%) experienced emotions of happiness, motivation and pride in oneself, while half just felt indifferent (see Figure 3). Only 17.62\% expressed negative responses towards this issue. When asked further whether they feel upset or depressed when comparing their body and looks with the images being portrayed in the advertisements in the media, $4.4 \%$ answered 'all the time', $65.2 \%$ 
responded 'sometimes', while 30. 4\% answered a firm 'never'. Surprisingly, from those who responded that the media portrayal does not impact them in any way earlier (52.72\%), only $32.30 \%$ of them, subsequently answered 'never', indicating a non-threatening emotional response among emerging adults at this institution. This is an encouraging finding to reveal that although the media does impact emerging adults in ways of sorts, yet, they are not adversely or emotionally distraught by its bombardments of ideal body images, a whole.

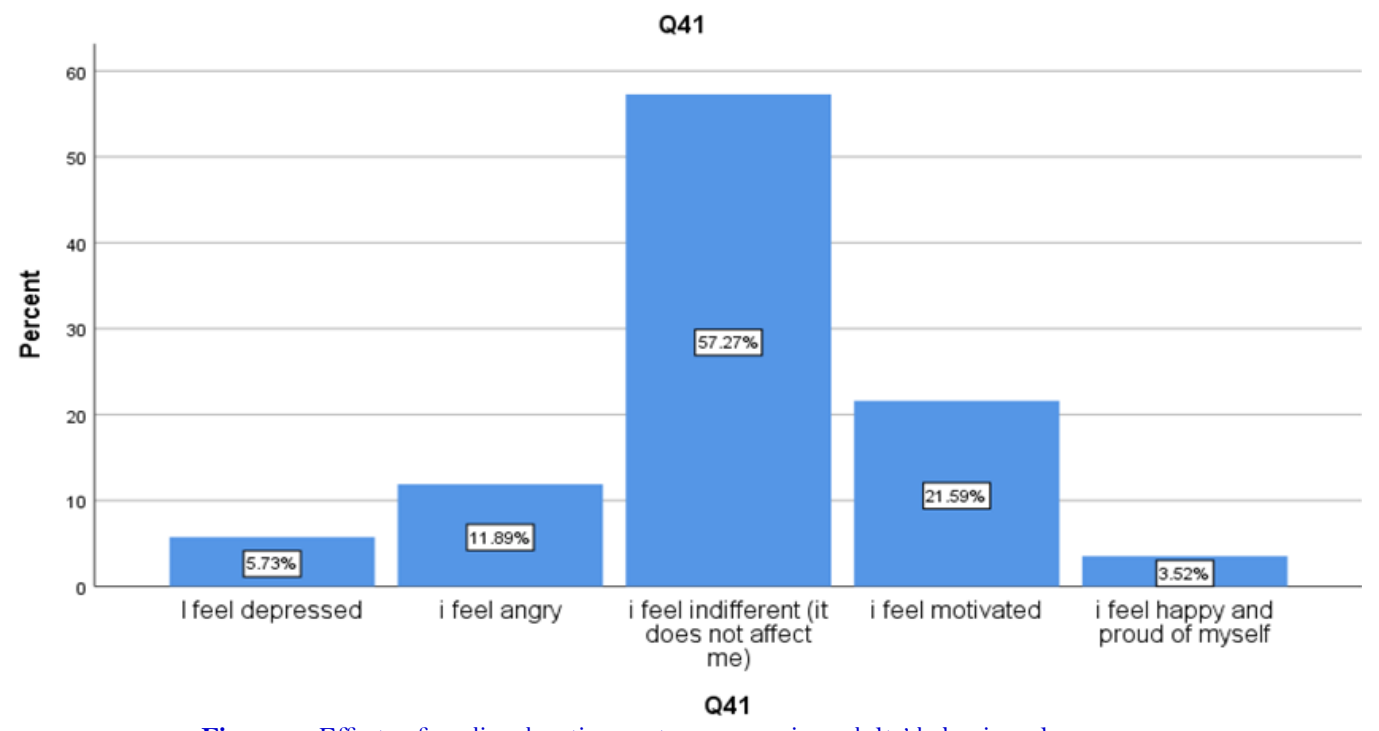

Figure 3. Effects of media advertisements on emerging adults' behavioural responses.

In propogating the notion of an ideal body image, advertisements often promote products related to weight loss, skincare or hair care. From Figure 4, we can see that understandably, a fraction of the participants (31.72\%) were most affected by weight loss product advertisement, 69 participants (30.4\%) felt unhappy with their skin condition, and only 28 participants (12.3\%) felt the need to have a lighter skin tone. The need to be thinner is consistent with previous findings such as the one by aforementioned, Reategui and Palmer (2017). However, the 12.8\% result of interest in skin lightening products is rather inconsistent with previous findings which highlight how lighter skin is perceived to be a sign of beauty, stature, and success (Li, Min, \& Belk, 2008) and thus, despite being aware of certain adverse effects they might face from using skin lightening products, users still persisted on trying their luck in getting the desired skin tone (Shankar \& Subish, 2016; Shroff, Diedrichs, \& Craddock, 2018). Fortunately, Malaysian emerging adults at this institution are not overly preoccupied with the notions of fair skin definition of beauty.

\section{Type of Media Advertisements' Effect on Body Image}

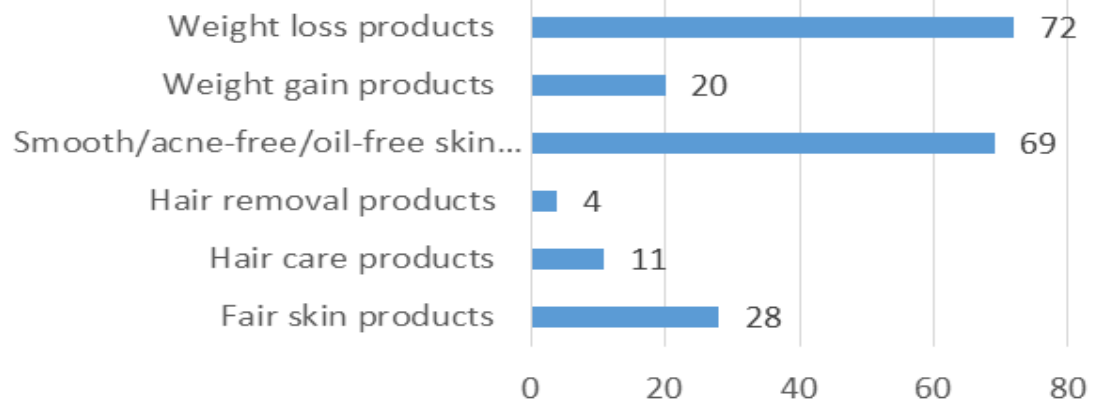

Figure 4. Influence of different types of media advertisements on emerging adults. 


\subsection{Emerging Adults' Behavioral Responses towards Media Advertising}

We further questioned our respondents regarding their responses when seeing these advertisements. Several respondents stated that their initial reaction was to feel angry towards the advertisement itself for portraying unrealistic images and expectations, but then their anger could also turn to self-dissatisfaction as they started comparing and criticizing their looks with the advertised image. However, this feeling was transient, and not long lasting, hence, the reaction is natural, negligible and does not represent the majority of emerging adults.

The majority of our respondents (36.1\%) mentioned that regardless of whether they would purchase the product or not, it is more important to quench their desire to seek more information regarding the advertised products rather than having to continuously think about it later. Interestingly, quite a number of them, 32.16\%, confidently stated that the advertisements made no impact on them as they accepted themselves the way they are.

There were overall positive changes recorded about respondents' behavioural responses and lifestyle as they strive towards improved image in response to media advertisements. The majority opted for changes depending on their target. While lifestyle changes such as exercising and taking better care of their diet could be considered healthier and cheaper options, some did not hesitate to spend their money on products such as collagen and vitamins, slimming equipment and drinks, or buying new or expensive self-care products. However, most were pleased with their result and deemed it as a success (40.97\%) but the rest had to settle on mediocre results despite trying almost everything $(40.1 \%)$. As the statistics are equally distributed, it can be said that investments in purported improvement is a gamble which could flip either way - towards positive results or otherwise.

From the responses collected, it is interesting to see that even though the difference between their comfort level when deciding what to wear for the day is not that large between 'yes' (47.14\%) and 'no' (52.86\%), however when asked whether they mind going out barefaced without any makeup, the majority did not mind doing so at all (56.39\%). Only $9.25 \%$ care about putting on makeup to feel comfortable leaving their home. This shows young adults seem to be more focused on their body shape than facial appearance in regard to body image confidence. This is consistent with the earlier findings when asked regarding the type of advertisement that affects them the most. However, this finding is contradictory to findings in previous studies which suggested facial attractiveness to be more important than physical attractiveness for body image (Currie \& Little, 2009; Rau, Gong, \& Zhuang, 2016).

\section{CONCLUSIONS AND RECOMMENDATIONS}

The study has found that the media as a whole, particularly social media exerts a strong and significant influence on emerging adults in Malaysia today. This influence is not only experienced by females, as popularly believed, but males are equally impacted by media influence, hence, there is strong urge for responsible and realistic media portrayal of males and females, as voiced out by the emerging adults of the study.

Although the study yielded significant correlation between media portrayal and emotional states, it is noteworthy that the emotional states experienced by young adults are not always negative, as shown by many previous studies. Instead, many young adults feel unfazed, unaffected or are just positively impacted through vibes of self-satisfaction and happiness from within. This study proves that young adults do have a certain degree of maturity to be able to distinguish between self-inflicting harmful emotions and positive emotions, therefore, are able to rationally take the positive path in viewing themselves against media portrayal of ideal body image among males and females.

A praiseworthy finding is that the majority of learners take the more rational and positive route in improving themselves and their body image post media advertisement bombardment onto their lives. Despite the constant flow and flooding of advertisements of ideal beauty, weight and skin tone, many young adults opt for exercise and change in diet regime. This is worthy of praise and ought to be lauded as emerging adults in Malaysia do demonstrate praiseworthy levels of rationality, positivity and growth mindset in improving themselves, implying that they are in the right direction, with guidance of parents, educators, or religious teaching which promotes sensibility and restraint self-indulgence. 
Additionally, important implications can be drawn from this study. Educators, parents, policy makers and the society at large need to wittingly awaken the minds of the youth about the strong impact the media imposes on the body image of emerging adults. In view of this particular care should be taken to ensure the overriding effects of media can be effectively mitigated through frequent reinforcements by the ones near and dear to Malaysian emerging adults, be it parents, peers, educators or the society at large.

As males and females are equally affected by body image projection by social media due to generational differences and advancement of media technology, media providers bear a moral and ethical responsibility of being aware of the pervading effects on media users, especially on the emerging adults. While currently, it is noted that majority if not all social media platforms do list certain requirements and terms of agreement for their users, stricter monitoring is essential as the eligibility age for social media users is being lowered and many of them are getting smarter in getting around social media rules. In this regard, we may emulate China which is currently working on enforcing such rules to its social media users (Hu \& Deng, 2021), and the rest of the world can take heed too so as to ensure we have a generation of emerging adults with a healthy body image, and are not overly consumed by media influence.

Funding: This study received no specific financial support.

Competing Interests: The authors declare that they have no competing interests.

Authors' Contributions: All authors contributed equally to the conception and design of the study.

\section{REFERENCES}

Ahmad, A. H., Idris, I., \& Jing, R. M. L. (2019). The effects of self-esteem and influence of friends via social media on body image amongst children. International Journal of Financial Research, 10(5), 40.Available at: https://doi.org/10.5430/ijfr.v10n5p40.

Barve, G., Sood, A., Nithya, S., \& Virmani, T. (2015). Effects of Advertising on Youth (Age Group of 13-19 Years Age). Journal Mass Communicat Journalism, 5(260), 2.Available at: https://doi.org/10.4172/2165-7912.1000260.

Bergenholtz, E. (2014). Body image among students in Beijing: Impact of media, status, and health concerns. [Master's Thesis, Lund University]. LUP Student Papers: LUND University Libraries.

Brennan, M. A., Lalonde, C. E., \& Bain, J. L. (2010). Body image perceptions: Do gender differences exist. Psi Chi Journal of Undergraduate Research, 15(3), 130-138.Available at: https://doi.org/10.24839/1089-4136.jn 15.3.130.

Brown, G. S. (2015). Collarbone challenge latest on social media to raise concern. ABC News. Retrieved from: https://abcnews.go.com/Lifestyle/collarbone-challenge-latest-social-media-raise-concern/story?id=31826265.

Chua, T. H. H., \& Chang, L. (2016). Follow me and like my beautiful selfies: Singapore teenage girls' engagement in selfpresentation and peer comparison on social media. Computers in Human Behavior, 55, 190-197.Available at: https://doi.org/10.1016/j.chb.2015.09.011.

Croll, J. (2005). Body image and adolescents. In Stang, J., \& Story, M. (Eds.). . (pp. 155-166). Minneapolis, MN: Guidelines for Adolescent Nutrition Services.

Currie, T. E., \& Little, A. C. (2009). The relative importance of the face and body in judgments of human physical attractiveness. Evolution and Human Behavior, 30(6), 409-416.Available at: https://doi.org/10.1016/j.evolhumbehav.2009.06.005.

Dromgoole, A. (2011). Media effects and body image perceptions on youth. [Master's Research Brief, Texas A\&M University]. Sequor Youth Development Initiative.

Ferguson, C. J., Muñoz, M. E., Garza, A., \& Galindo, M. (2014). Concurrent and prospective analyses of peer, television and social media influences on body dissatisfaction, eating disorder symptoms and life satisfaction in adolescent girls. Journal of Youth and Adolescence, 43(1), 1-14.Available at: https://doi.org/10.1007/s 10964-012-9898-9.

George, H. R. (2010). The effects of media exposure on body dissatisfaction and cognitive bias in adolescent girls and boys. Unpublished Doctoral Theses, University of Leeds, UK.

Gerbner, G., \& Gross, L. (1976). Living with television: The violence profile. Journal of Communication, 26(2), 172-199.Available at: https://doi.org/10.1111/j.1460-2466.1976.tbo1397.x. 
Geyser, W. (2021). What is an influencer? - Social media influencers defined. Influencer Marketing Hub. Retrieved from: https://influencermarketinghub.com/what-is-an-influencer/.

Grogan, S. (2016). Body image: Understanding body dissatisfaction in men women and children (3rd ed.): Routledge.

Harrison, K. (2000). The body electric: Thin-ideal media and eating disorders in adolescents. Journal of Communication, 50(3), 119143.Available at: https://doi.org/10.1111/j.1460-2466.2000.tb02856.x.

Holland, G., \& Tiggemann, M. (2016). A systematic review of the impact of the use of social networking sites on body image and disordered eating outcomes. Body Image, 17, 100-1 10.Available at: https://doi.org/doi:10.1016/j.bodyim.2016.02.008.

Hu, M., \& Deng, I. (2021). China updates rules on social media accounts, increasing the already high cost of moderation. The Star.

Retrieved from; https://www.thestar.com.my/tech/tech-news/2021/01/26/china-updates-rules-on-social-mediaaccounts-increasing-the-already-high-cost-of-moderation.

Kemp, S. (2021). Digital 2021 : Global overview report. Data Reportal. Retrieved from: https://datareportal.com/reports/digital2021 -global-overview-report.

Knauss, C., Paxton, S. J., \& Alsaker, F. D. (2007). Relationships amongst body dissatisfaction, internalization of the media body ideal and perceived pressure from media in adolescent girls and boys. Body Image, 4, 353-360.Available at: https://doi.org/10.1016/j.bodyim.2007.06.007.

Koyuncu, M., Tok, S., Canpolat, A. M., \& Catikkas, F. (2010). Body image satisfaction and dissatisfaction, social physique anxiety, self-esteem, and body fat ratio in female exercisers and nonexercisers. Social Behavior and Personality: an international journal, 38(4), 56 1-570.Available at: https://doi.org/10.2224/sbp.2010.38.4.561.

Li, E. P., Min, H. J., \& Belk, R. W. (2008). Skin lightening and beauty in four Asian cultures, in NA - Advances in Consumer Research eds. Angela Y. Lee and Dilip Soman (Vol. 35, pp. 444-449). Duluth, MN: Association for Consumer Research.

Malaysian Communications and Multimedia Commision. (2020). Internet users survey 2020. Retrieved from: https://www.mcmc.gov.my/skmmgovmy/media/General/pdf/IUS-2020-Report.pdf.

Mills, J. S., Shannon, A., \& Hogue, J. (2017). Beauty, body image, and the media. In M.P. Levine (Ed.), Perceptions of Beauty (pp. 145-157): IntechOpen.

Moy, G. (2015). Media, family, and peer influence on children's body image. Bachelor's Thesis, Rutgers University. RUcore: Rutgers University Community Repository.

Moyer, J. W. (2015). Kylie Jenner lip challenge: The dangers of 'plumping that pout. The Washington Post. Retrieved from: https://www.washingtonpost.com/news/morning-mix/wp/2015/04/21/kylie-jenner-challenge-the-dangers-ofplumping-that-pout/.

Munsey, C. (2006). Emerging adults: The in-between age. Monitor on Psychology, 37(6), 68.

Noh, J.-W., Kwon, Y. D., Yang, Y., Cheon, J., \& Kim, J. (2018). Relationship between body image and weight status in east Asian countries: Comparison between South Korea and Taiwan. BMC Public Health, 18(1), 1-8.Available at: https://doi.org/10.1186/s12889-018-5738-5.

Olsen, J. (2015). Connections between kids' media use and body image. Michigan State University Extension. Retrieved from: https://www.canr.msu.edu/news/connections between kids media use and body image.

Rau, P.-L. P., Gong, Y., \& Zhuang, C. (2016). Pretty face matters: Relative importance of the face and body attractiveness in China. Psychology, 7(7), 1034-1042.Available at: https://doi.org/10.4236/psych.2016.77104.

Reategui, A. S. L., \& Palmer, R. (2017). Unfiltered: The effect of media on body image dissatisfaction. International Journal of Social Science and Humanity, 7(6), 367-372.

Rickert, A., \& Sacharow, A. (2000). It's a woman's world wide web. media metrix and Jupiter communications. Retrieved from; https://www.yumpu.com/en/document/read/17041537/media-metrix-jupiter-communications-its-a-noticiasdotcom.

Schiffer, J. (2021). You may not want to get your beauty tips from TikTok. The New York Times. Retrieved from: https://www.nytimes.com/2021/06/15/style/you-may-not-want-to-get-your-beauty-tips-from-tiktok.html.

Shankar, P. R., \& Subish, P. (2016). Fair skin in South Asia: an obsession? Journal of Pakistan Association of Dermatology, 17(2), 100104. 
Shroff, H., Diedrichs, P. C., \& Craddock, N. (2018). Skin color, cultural capital, and beauty products: An investigation of the use of skin fairness products in Mumbai, India. Frontiers in Public Health, 5, 365.Available at: https://doi.org/10.3389/fpubh.2017.00365.

Solomon, M. R., Ashmore, R. D., \& Longo, L. C. (1992). The beauty match-up hypothesis: Congruence between types of beauty and product images in advertising. Journal of Advertising, 21(4), 23-34.Available at: https://doi.org/10.1080/00913367.1992.10673383.

Tehranian, Y. (2013). Social media, social kids: sociocultural implications of 21st century media for development in the preteen period. Unpublished Doctoral Dissertation. University of California.

Thompson, J. K., Heinberg, L. J., Altabe, M., \& Tantleff-Dunn, S. (1999). Sociocultural theory: The media and society. In J. K. Thompson, L. J. Heinberg, M. Altabe, \& S. Tantleff-Dunn, Exacting beauty: Theory, assessment, and treatment of body image disturbance (pp. 85-124): American Psychological Association.

Tiggemann, M. (2003). Media exposure, body dissatisfaction and disordered eating: Television and magazines are not the same! European Eating Disorders Review: The Professional Journal of the Eating Disorders Association, 11(5), 418-430.Available at: https://doi.org/10.1002/erv.502.

Tiidenberg, K. (2014). Bringing sexy back: Reclaiming the body aesthetic via self-shooting. Cyberpsychology: Journal of Psychosocial Research on Cyberspace, 8(1), 1-3.Available at: https://doi.org/10.5817/CP2014-1-3.

Voges, M. M., Giabbiconi, C. M., Schöne, B., Waldorf, G., Hartmann, A. S., \& Vocks, S. (2019). Gender differences in body evaluation: Do men show more self-serving double standards than women? Frontiers. Retrieved from; https://www.frontiersin.org/articles/10.3389/fpsyg.2019.00544/full.

Yan, Y., \& Bissell, K. (2014). The globalization of beauty: How is ideal beauty influenced by globally published fashion and beauty magazines? Journal of Intercultural Communication Research, 43(3), 194-214.Available at: https://doi.org/10.1080/17475759.2014.917432.

Views and opinions expressed in this article are the views and opinions of the author(s), International Journal of Asian Social Science shall not be responsible or answerable for any loss, damage or liability etc. caused in relation to/arising out of the use of the content. 